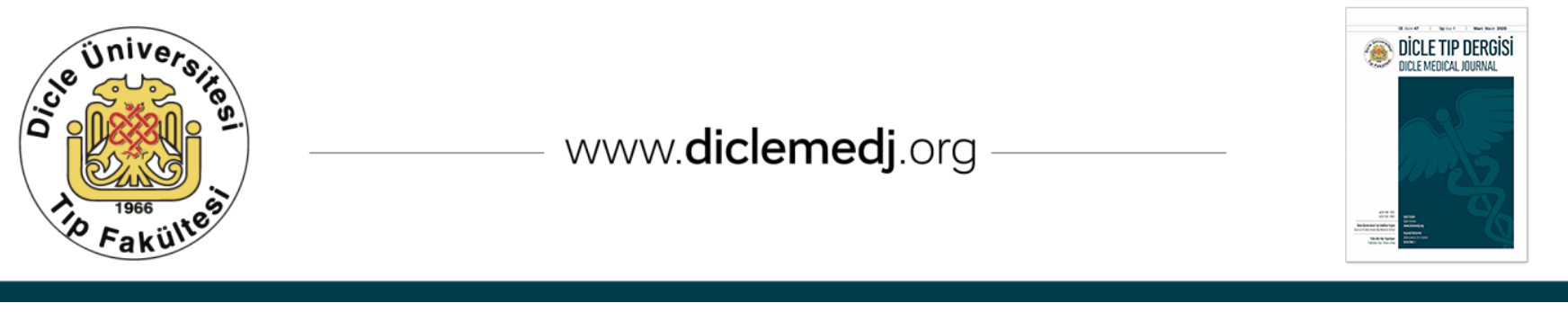

\title{
Analysis of Patients Undergoing Peripartum Hysterectomy for Obstetric Causes According to Delivery Methods: 13-Year Experience of a Tertiary Center
}

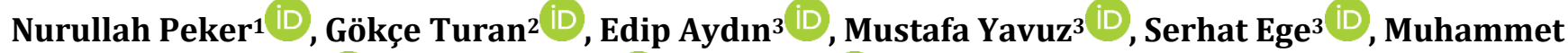 \\ Hanifi Bademkıran $^{3}$ (D), Talip Karaçor ${ }^{4}$ iD, Talip Gül1 ${ }^{1}$ \\ 1 Department of Obstetrics and Gynecology, Dicle University, Faculty of Medicine, Diyarbakır, Turkey \\ 2 Department of Obstetrics and Gynecology, Gazi University, Ankara, Turkey \\ 3 Department of Obstetrics and Gynecology, Health Sciences University, Gazi Yasargil Training and Research Hospital, Diyarbakir, Turkey \\ 4 Department of Obstetrics and Gynecology, Adlyaman University, Faculty of Medicine, Adlyaman, Turkey
}

Received: 26.11.2019; Revised: 07.01.2020; Accepted: 21.01.2020

\begin{abstract}
Objective: The aim of this study was to examine the maternal and fetal outcomes of patients undergoing peripartum hysterectomy (PH) after vaginal delivery (VD) and cesarean section (C/S).

Methods: The files of patients undergoing PH following postpartum hemorrhage (PPH) between January 2005 and November 2018 were reviewed retrospectively. Patients undergoing PH were divided into two groups as C/S and VD. Age, parity, gestational weeks, time between delivery and hysterectomy, estimated blood loss, duration of operation, number of blood transfusions, hospitalization time, APGAR scores of the fetus at the 1st and 5th minutes, previous C/S histories, fetal and maternal mortality, indications for $\mathrm{PH}$, additional surgeries performed during $\mathrm{PH}$, and pre-op and postop complications were recorded retrospectively and the groups were compared.
\end{abstract}

Results: A total of 147 patients who underwent PH for postpartum PPH were identified. Of the patients included in the study, 77 underwent PH after VD and 70 underwent PH after C/S. There was no statistically significant difference between the groups in terms of age, parity, time between delivery and hysterectomy, estimated blood loss, number of blood transfusions, hospitalisation time, and maternal mortality rates. The gestational weeks of the patients in the VD group were higher than that of the patients in the $\mathrm{C} / \mathrm{S}$ group $(\mathrm{P}=0.003)$. Mean duration of operation of the $\mathrm{C} / \mathrm{S}$ group was longer than that of the VD group ( $\mathrm{P}<0.001)$. APGAR scores of the fetus at the 1 st and 5 th minutes were higher in the VD group compared to the $\mathrm{C} / \mathrm{S}$ group $(\mathrm{P}<0.001, \mathrm{P}<0.001$, respectively). The most common indication for $\mathrm{PH}$ was uterine atony in the VD group (n: 54, 70.1\%) and uterine rupture in the C/S group (n: 24, 34.2\%). Disseminated intravascular coagulopathy (DIC) was the most common complication in both groups.

DOI: 10.5798/dicletip.706086

Correspondence / Yazışma Adresi: Nurullah Peker, Department of Obstetrics and Gynecology, Dicle University, Faculty of Medicine, 21070, Diyarbakir, Turkey e-mail: dr_nurullah_peker@hotmail.com 
Conclusion: While fetal mortality and morbidity are higher in patients undergoing hysterectomy after $\mathrm{C} / \mathrm{S}$, long-term effects caused by C/S (previous C/S, placenta accreta, placenta previa) increase PH risk. However, it should also be considered that PH risk may increase after VD as well.

Keywords: Peripartum hysterectomy, cesarean section, vaginal delivery, postpartum hemorrhage

\section{Obstetrik Nedenlerle Peripartum Histerektomi Yapılan Hastaların Doğum Şekillerine Göre Analizi: Tersiyer Merkezin 13 Yıllık Deneyimi}

Öz

Amaç: $\mathrm{Bu}$ çalışmada vajinal doğum (VD) sonrası ve sezaryen doğum (C/S) sonrası peripartum histerektomi (PH) uygulanan hastaların maternal ve fetal sonuçlarını incelemek amaçlandı.

Yöntemler: Ocak 2005 ile Kasım 2018 tarihleri arasında tersiyer bir merkezde postpartum kanama (PPK) sonrası PH olan hastaların dosyaları retrospektif olarak incelendi. PH olan hastalar C/S sonrası ve VD sonrası olmak üzere iki gruba ayrıldı. Tüm hastaların yaşları, parite sayıları, gebelik haftaları, doğum ile histerektomi arası geçen süreleri, tahmini kan kayıpları, operasyon süreleri, kan transfüzyonu sayıları, hastanede yatış süreleri, fetüsün 1.ve 5.dakika APGAR skorları, geçirilmiş C/S öyküleri, fetal ölüm ve maternal ölüm durumları, PH endikasyonları, PH operasyonu sırasında yapılan ek cerrahiler, cerrahi sırasında veya sonrasında olan komplikasyonlar retrospektif olarak kaydedildi ve gruplar birbiri ile karşılaştırıldı.

Bulgular: Doğum sonrası PPK nedeni ile PH yapılan 147 hasta tespit edildi. Çalışmaya dahil edilen hastaların 77'sine VD sonrası ve 70'ine C/S sonrası PH uygulandı. Grupların yaş, parite, doğum ile histerektomi arası geçen süreleri, tahmini kan kayıpları, yapılan kan transfüzyonu sayıları, hastanede yatış süreleri, maternal ölüm oranları arasında istatistiksel olarak fark izlenmedi. VD grubundaki hastaların gestasyonel haftaları, C/S grubundaki hastaların gestasyonel hastalarına oranla daha yüksekti (p:0.003). C/S grubunun operasyon süreleri VD grubuna göre daha uzundu ( $<<0.001)$. VD grubundaki hastaların bebeklerinin 1.ve 5.dakika APGAR skorları, C/S grubuna oranla daha yüksekti (sırasıyla $\mathrm{p}<0.001$, $\mathrm{p}<0.001)$. VD grubundaki hastaların en sık (n:54, \%70,1) uterin atoni nedenli, C/S grubundaki hastaların ise en sık (n:24, \%34,2) uterin rüptür nedenli PH olduğu görüldü. Her iki grupta da en sık görülen komplikasyonun ise dissemine intravasküler koagülopati (DİK) olduğu tespit edildi.

Sonuç: C/S sonrası histerektomi olan hastalarda fetal mortalite ve morbidite daha fazla iken, C/S operasyonun neden olduğu uzun dönemli sonuçlar (geçirilmiş C/S, plasenta akreata, plasenta previa) PH riskini artırmaktadır. Ancak VD sonrası da PH riskinin artabileceği göz önünde bulundurulmalıdır.

Anahtar kelimeler: Peripartum histerektomi, sezaryen, vajinal doğum, postpartum hemoraji.

\section{INTRODUCTION}

Postpartum hemorrhage (PPH) is a potentially preventable obstetric emergency occurring after both vaginal delivery (VD) and cesarean section (C/S). PPH is the main cause of maternal mortality worldwide ${ }^{1,2}$. Maternal mortality due to $\mathrm{PPH}$ vary between $1 \%$ and $5 \%$ in all deliveries ${ }^{3}$. Since PPH is preventable, accurate and early diagnosis is crucial to prevent maternal mortality. PPH is defined as blood loss of more than $500 \mathrm{ml}$ in the first 24 hours after VD, or more than $1000 \mathrm{ml}$ after $\mathrm{C} / \mathrm{S}^{4}$.
Peripartum hysterectomy (PH) is usually performed to prevent maternal mortality in lifethreatening obstetric hemorrhage cases and is therefore considered as "near-miss" 5 . PH is generally used as a life-saving treatment of massive bleeding when other medical or conservative surgical treatments fail. Its incidence is 0.4 per 1000 births in developed countries, while in underdeveloped countries the incidence is ${ }^{5}$ per 1000 births $^{6}$. Known risk factors for $\mathrm{PH}$ are advanced maternal age, abnormal placentation, high parity number, and $\mathrm{C} / \mathrm{S}$ history in current or previous 
pregnancies ${ }^{7,8}$. While uterine atony and uterine rupture were the most common causes of $\mathrm{PH}$ in previous years, these rates started to decrease with intrapartum and postpartum follow-up methods and increasing $\mathrm{C} / \mathrm{S}$ rates, placental invasion anomalies, and placenta previa became the most common cause of $\mathrm{PH}$ in recent years ${ }^{9-}$ 11.

The aim of this study was to compare the indications, postoperative or intraoperative complications, and maternal and fetal outcomes of patients who underwent PH after VD and C/S.

\section{METHODS}

The files of patients who underwent $\mathrm{PH}$ due to PPH in a tertiary center between January 2005 and November 2018 were reviewed retrospectively. Ethics committee approval for the study (ethics committee number: 182) was obtained from our hospital. Patients who underwent hysterectomy for gynecological indications, patients referred to our clinic due to PPH after VD or C/S in an external center, patients whose gestational week was less than 24 weeks, and patients with incomplete or insufficient hospital records were excluded from the study. Patients with PPH within 24 hours after VD or C/S who underwent PH after failure to control bleeding with medical treatment (oxytocin, methergine, misoprostol) and surgical treatment (uterine fundal massage, postpartum uterine curettage, Bakri balloon, bLynch, Hayman suture, etc.) were included in the study. Patients undergoing $\mathrm{PH}$ were divided into two groups as post C/S and post VD. Age, parity, gestational weeks, time between delivery and hysterectomy, estimated blood loss, duration of operation, number of blood transfusions, hospitalization time, APGAR scores of the fetus at the 1 st and 5 th minutes, previous $\mathrm{C} / \mathrm{S}$ histories, fetal and maternal mortality, indications for $\mathrm{PH}$, additional surgeries performed during $\mathrm{PH}$, and complications during or after surgery were recorded retrospectively from patient files and the groups were compared. The gestational week of the patients was calculated based on the last menstrual date (LMD). For patients who did not remember their LMDs, first trimester ultrasonography recordings were used to calculate the gestational week. Hospitalisation time was defined as the time between the day of delivery and the day of discharge. Patients receiving blood transfusions were those who periodically lost more than $20 \%$ of their total blood volume (patients with postoperative hemoglobin values below $7 \mathrm{~g} / \mathrm{dl}$ or patients with symptoms of anemia).

Statistical Package for Social Sciences 20.0 (SPSS Inc., Chicago, IL, USA) was used for statistical analysis. The distribution of the data was evaluated by Kolmogorov-Smirnov test. Descriptive statistical methods (mean, standard deviation) were used. Pearson chi-square test was used for comparison of groups. A p value of $<0.05$ was accepted as statistically significant.

\section{RESULTS}

Between January 2005 and November 2018, a total of 289,793 deliveries were performed in our center, including 218,437 VD and 71,356 C/S deliveries. There were 147 patients who underwent $\mathrm{PH}$ after delivery. Of the patients included in the study, 77 underwent PH after VD and 70 underwent $\mathrm{PH}$ after $\mathrm{C} / \mathrm{S}$. Table I lists the demographic data and operational characteristics of the groups. There was no statistically significant difference between the groups in terms of age, parity, time between delivery and hysterectomy, estimated blood loss, number of blood transfusions, hospitalisation time, and maternal mortality rates. The gestational weeks of the patients in the VD group were higher than that of the patients in the $C / S$ group $(P=0.003)$. Mean duration of operation of the $\mathrm{C} / \mathrm{S}$ group was longer than that of the VD group $(\mathrm{P}<0.001)$. APGAR scores of the fetus at the 1 st and 5 th minutes were higher in the VD group compared 
to the $\mathrm{C} / \mathrm{S}$ group $(\mathrm{P}<0.001, \mathrm{P}<0.001$, respectively). The rate of fetal mortality and hypogastric artery ligation (HGAL) during $\mathrm{PH}$ were significantly higher in the $\mathrm{C} / \mathrm{S}$ group.

Table 1: Demographic Data and Operation Characteristics of Groups

\begin{tabular}{|c|c|c|c|c|}
\hline \multicolumn{2}{|l|}{ Characteristics } & VD $(n=77)$ & $\mathrm{C} / \mathrm{S}(\mathrm{n}=70)$ & p-value \\
\hline \multicolumn{2}{|l|}{ Age } & $33.7 \pm 5.6$ & $34.1 \pm 6.1$ & 0.70 \\
\hline \multicolumn{2}{|l|}{ Parity } & $4.8 \pm 2.7$ & $4.6 \pm 2.3$ & 0.68 \\
\hline \multicolumn{2}{|l|}{ Gestational Week } & $38.5 \pm 2.6$ & $36.8 \pm 3.8$ & 0.003 \\
\hline \multicolumn{2}{|c|}{$\begin{array}{l}\text { Time between delivery and } \\
\text { hysterectomy ( } \mathrm{min})\end{array}$} & $158 \pm 138$ & $105 \pm 108$ & 0.12 \\
\hline \multicolumn{2}{|c|}{ Estimated blood loss (ml) } & $2603 \pm 844$ & $2571 \pm 1009$ & 0.83 \\
\hline \multicolumn{2}{|c|}{ Duration of operation (min) } & $105.1 \pm 44.8$ & $135.5 \pm 55.2$ & $<0.001$ \\
\hline \multicolumn{2}{|l|}{ Blood Transfusion } & $5.1 \pm 2.1$ & $5.2 \pm 1.9$ & 0.71 \\
\hline \multicolumn{2}{|c|}{ 1st Minute APGAR score } & $5.6 \pm 2.4$ & $3.6 \pm 2.7$ & $<0.001$ \\
\hline \multicolumn{2}{|c|}{ 5th Minute APGAR score } & $7.9 \pm 2.5$ & $5.7 \pm 3.5$ & $<0.001$ \\
\hline \multicolumn{2}{|l|}{ Hospitalization (days) } & $5.5 \pm 2.6$ & $5.3 \pm 2.4$ & 0.58 \\
\hline HGAL & Yes & $\begin{array}{l}13 / 77 \\
(16.9 \%)\end{array}$ & $\begin{array}{l}22 / 70 \\
(31.4 \%)\end{array}$ & 0.03 \\
\hline $\begin{array}{l}\text { Previous caesarean } \\
\text { section }\end{array}$ & Yes & $0 / 77(0 \%)$ & $\begin{array}{l}24 / 70 \\
(34.3 \%)\end{array}$ & $<0.001$ \\
\hline Fetal mortality & Yes & $6 / 77(7.8 \%)$ & $21 / 70(30 \%)$ & 0.001 \\
\hline Maternal mortality & Yes & $3 / 77(3.9 \%)$ & $1 / 70(1.4 \%)$ & 0.06 \\
\hline
\end{tabular}

HGAL: Hypogastric artery ligation

Table II lists the indications for $\mathrm{PH}$, additional surgeries during the operation, and complications. The most common indication for $\mathrm{PH}$ was uterine atony in the VD group (n: 54, $70.1 \%$ ) followed by uterine rupture (n: 23, $29.8 \%$ ), and uterine rupture in the $\mathrm{C} / \mathrm{S}$ group (n: $24,34.2 \%$ ) followed by uterine atony (n: 23 , $32.8 \%)$. While the majority of patients with VD and $\mathrm{C} / \mathrm{S}$ delivery did not undergo any additional surgery during $\mathrm{PH} \quad(76.6 \%$ and $67.1 \%$, respectively), HGAL was the most commonly used procedure $(16.8 \%$ and $31.4 \%$, respectively). Complications were not seen in the majority of both groups after PH. Disseminated intravascular coagulopathy (DIC) was the most common complication in both groups.

Table 2: PH Indications, Additional Surgical Operations, and Postoperative Complications

\begin{tabular}{|c|c|c|c|}
\hline Characteristics & & VD $(n=77)$ & $\begin{array}{l}C / S \\
(n=70)\end{array}$ \\
\hline \multirow{6}{*}{$\begin{array}{l}\text { Indication } \\
\text { Hysterectomy }\end{array}$} & Atony & $54(70.1 \%)$ & $23(32.8 \%)$ \\
\hline & Uterine rupture & $23(29.8 \%)$ & $24(34.2 \%)$ \\
\hline & Placenta previa & - & $2(2.8 \%)$ \\
\hline & Placenta accrete & - & $14(20 \%)$ \\
\hline & $\begin{array}{l}\text { Placental } \\
\text { abruption }\end{array}$ & - & $5(7.1 \%)$ \\
\hline & $\begin{array}{l}\text { Incision site } \\
\text { bleeding }\end{array}$ & - & $2(2.8 \%)$ \\
\hline \multirow{4}{*}{ Additional surgeries } & None & $59(76.6 \%)$ & $47(67.1 \%)$ \\
\hline & USO & $1(1.2 \%)$ & - \\
\hline & HGAL+USO & $3(3.8 \%)$ & $1(1.4 \%)$ \\
\hline & $\mathrm{HGAL}+\mathrm{BSO}$ & $1(1.2 \%)$ & - \\
\hline \multirow{9}{*}{ Complications } & None & $39(50.6 \%)$ & $23(32.8 \%)$ \\
\hline & Bladder injury & $1(1.2 \%)$ & $9(12.8 \%)$ \\
\hline & DIC & $11(14.2 \%)$ & $11(15.7 \%)$ \\
\hline & Fever & $5(6.4 \%)$ & $7(10 \%)$ \\
\hline & $\begin{array}{l}\text { Wound site } \\
\text { Infection }\end{array}$ & $10(12.9 \%)$ & $9(12.8 \%)$ \\
\hline & ARF & - & $3(4.2 \%)$ \\
\hline & PTE & $4(5.1 \%)$ & $1(1.4 \%)$ \\
\hline & Ureteral injury & $2(2.5 \%)$ & $2(2.8 \%)$ \\
\hline & Ileus & $5(6.4 \%)$ & $5(7.1 \%)$ \\
\hline
\end{tabular}

ARF: acute renal failure USO: unilateral salpingo-oophorectomy, BSO: bilateral salpingo-oophorectomy PTE: pulmonary thromboembolism DIC: Disseminated intravascular coagulopathy 


\section{DISCUSSION}

In this study, maternal and fetal outcomes, demographic data, and operation characteristics of patients undergoing $\mathrm{PH}$ after VD and C/S were compared. While the VD group had higher APGAR scores at the 1st and 5th minutes, fetal mortality rate and HGAL during $\mathrm{PH}$ were higher in the $\mathrm{C} / \mathrm{S}$ group. The most common indication for $\mathrm{PH}$ was uterine atony in the VD group (n: $54,70.1 \%$ ) and uterine rupture in the C/S group (n: 24, 34.2\%). In addition, fetal mortality and morbidity were higher in the $\mathrm{C} / \mathrm{S}$ group.

$\mathrm{PH}$ is the last life-saving treatment for PPH cases that cannot be controlled by medical or surgical treatment ${ }^{12}$. It can be applied in PPHs after C/S (cesarean hysterectomy) or VD (postpartum hysterectomy). Although the rate of $\mathrm{PH}$ varies by country, it has been reported in rates ranging from 0.2 to 2.7 per 1000 births $^{13-15}$. While the rates in Europe range from 0.2 to 1 per 1000 births ${ }^{16}$, studies in Turkey report rates of 4.68/1000 and 5.09/100014,17. In our study, the rate of $\mathrm{PH}$ in the specified time interval was found to be 5 in 10,000 births (147 in 289,793 births). This rate is lower than those reported in the literature. This low rate can be attributed to several reasons: Since our clinic is a tertiary center and hospital conditions are favourable, $\mathrm{PH}$ is not preferred initially for patients with $\mathrm{PPH}$ and procedures such as Bakri balloon, Blynch, Hayman suture, HGAL, uterine artery ligation, and segmental resection are applied liberally. Therefore, PH rates may be lower because many patients benefit from the procedures without having to undergo $\mathrm{PH}$.

In the present study, the most common cause of $\mathrm{PH}$ after VD was uterine atony with $70.1 \%$ and the most common cause of $\mathrm{PH}$ after $\mathrm{C} / \mathrm{S}$ was uterine rupture with $34.2 \%$. It has been reported in the literature that $\mathrm{PH}$ rates due to uterine atony indication are decreasing, whereas $\mathrm{PH}$ rates due to placental accreta are increasing 18. The most important reason for this has been reported to be the increasing $\mathrm{C} / \mathrm{S}$ ratios in recent years ${ }^{18}$. These indication differences may be due to differences in $\mathrm{C} / \mathrm{S}$ rates and approaches to obstetric hemorrhage in various countries. It is also remarkable that $29.8 \%$ of VD patients underwent $\mathrm{PH}$ due to uterine rupture. In a study conducted in Turkey, it was reported that $69.2 \%$ of patients with unscarred uterine rupture after VD underwent $\mathrm{PH}^{19}$. The low rate in the present study may be due to the difference in demographics data between the studies.

The most important point that should be kept in mind in patients undergoing $\mathrm{PH}$ is the preparation of necessary and sufficient blood products especially in patients with $\mathrm{C} / \mathrm{S}$ history with placental previa or placental invasion anomaly since there may be excessive blood loss due to obstetric bleeding19. Studies have reported that patients undergoing $\mathrm{PH}$ may require an average of 4-6 units of erythrocyte suspension $(E S)^{20}$. In the present study, no statistically significant difference was observed in the number of blood transfusions between the two groups $(\mathrm{P}=0.71)$. However, in the VD and C/S groups, $5.1 \pm 2.1$ and $5.2 \pm 1.9$ units of ES transfusion were performed, respectively. This rate is consistent with the literature. In addition, HGAL was performed in $31.4 \%$ of the C/S group and $16.8 \%$ of the VD group to control bleeding during $\mathrm{PH}$. This ratio is higher in the $\mathrm{C} / \mathrm{S}$ group since indications for $\mathrm{PH}$ include placenta previa (2.8\%), placenta accreta (20\%) and placental abruption (7.1\%), and therefore the need for HGAL may have arisen.

PH can cause many complications, such as increased number of massive transfusions, DIC, urinary tract injury, and febrile morbidity 4,21 . In the present study, the most common complication in the C/S group was DIC, while the second most common complication was bladder injury. In the VD group, the most common complication was again DIC. DIC secondary to excessive blood loss as a result of 
obstetric bleeding is an expected condition. In addition, due to the fact that our center is a referral hospital, the time taken during the transfer of patients to our clinic may have increased the blood loss and thus led to DIC being the most common complication.

In the present study, none of the patients in the VD group had a history of $\mathrm{C} / \mathrm{S}$. In the $\mathrm{C} / \mathrm{S}$ group, $34 \%$ of the patients had a previous $\mathrm{C} / \mathrm{S}$ history $(\mathrm{P}<0.001) . \mathrm{C} / \mathrm{S}$ history may have an effect on the higher rate of bladder injury in the $\mathrm{C} / \mathrm{S}$ group. In the literature, the rate of bladder injury during PH varies between 9-15\% 4,14. The rate of bladder injury in the present study was $12.8 \%$ in the $\mathrm{C} / \mathrm{S}$ group and $1.2 \%$ in the VD group. The rate of bladder injury in the $\mathrm{C} / \mathrm{S}$ group is consistent with the literature and the probable cause is adhesions in the vesicouterine pouch due to $\mathrm{C} / \mathrm{S}$.

In a study conducted in Turkey, maternal mortality rate was reported as $16.7 \% 14$. Maternal mortality rate was reported as $0.6 \%$ in the UK 11, and $23821 \%$ in Nigeria ${ }^{22}$. In the present study, 3 cases $(3.9 \%)$ in the VD group and 1 case $(1.4 \%)$ in the $\mathrm{C} / \mathrm{S}$ group resulted in maternal mortality and this was not associated with the mode of delivery $(\mathrm{P}=0.06)$. However, it should be kept in mind that maternal mortality rates are high in obstetric bleeding. These rates may be associated with differences in geography, low antenatal follow-up, differences in socio-economic level, and time taken during the transfer of patients to advanced centers.

When the fetal outcomes of the groups were examined, APGAR scores at the 1st and 5th minutes were lower $(P<0.001)$ and fetal mortality rate $(30 \%)$ was significantly higher in the $\mathrm{C} / \mathrm{S}$ group $(\mathrm{P}=0.001)$. To the best of our knowledge, there are no publications in the literature comparing fetal outcomes with $\mathrm{PH}$. The low APGAR scores in the C/S group in our study and the high fetal mortality rate may be due to the higher rate of uterine rupture in the
$\mathrm{C} / \mathrm{S}$ group compared to the VD group. In addition, while patients with placenta previa, placenta accreta, and previous $\mathrm{C} / \mathrm{S}$ history were non-existent in the VD group, the presence of these patients only in the C/S group may have increased fetal mortality and resulted in a low APGAR score. In addition, the significantly higher duration of operation in the C/S group may have an effect on the delivery time of the fetus, as previous C/Ss may increase the duration of the operation, resulting in low APGAR scores and increased fetal morbidity. Another reason was that gestational week in the $\mathrm{C} / \mathrm{S}$ group was significantly lower compared to the VD group. This may have increased fetal morbidity and mortality.

Retrospective nature of this study is a limitation. Prospective studies with broader patient groups can be performed. However, the high number of patients and the evaluation of a 13-year period are the strengths of this study.

\section{CONCLUSION}

While fetal mortality and morbidity are higher in patients undergoing hysterectomy after $\mathrm{C} / \mathrm{S}$, long-term effects caused by $\mathrm{C} / \mathrm{S}$ (previous $\mathrm{C} / \mathrm{S}$, placenta accreta, placenta previa) increase $\mathrm{PH}$ risk. However, it should also be considered that PH risk may increase after VD as well.

Ethics Committee Approval: Ethics committee approval for the study (ethics committee number: 182) was obtained from our hospital.

Acknowledgements: We would like to thank Fesih Aktar his assistance with the statistics used in this report.

Declaration of Conflicting Interests: The authors declare that they have no conflict of interest.

Financial Disclosure: No financial support was received. 


\section{REFERENCES}

1. Donati S, Maraschini A, Lega I, et al. Maternal mortality in Italy: Results and perspectives of record-linkage analysis. Acta Obstet Gynecol Scand 2018; 97: 1317-24.

2. Kassebaum NJ, Bertozzi-Villa A, Coggeshall MS, et al. Global, regional, and national levels and causes of maternal mortality during 19902013: A systematic analysis for the Global Burden of Disease Study 2013. Lancet 2014; 384: 980-1004.

3. Lu MC, Fridman M, Korst LM, et al. Variations in the incidence of postpartum hemorrhage across hospitals in California. Matern Child Health J 2005; 9: 297-306.

4. Kwee A, Bots ML, Visser GHA, Bruinse HW. Emergency peripartum hysterectomy: A prospective study in the Netherlands. Eur J Obstet Gynecol Reprod Biol 2006; 124: 187-92.

5. World Health Organization. "Evaluating the quality of care for severe pregnancy complications: the WHO near-miss approach for maternal health. ". Geneva WHO 2011; 29.

6. Evsen M. S., Sak M. E., Özkul Ö., Bozkurt Y., Kapan M. Acil peripartum histerektomi. Dicle Med Journal/Dicle Tip Derg 2009; 1: 36.

7. Dogan 0, Pulatoglu C, Yassa M. A new facilitating technique for postpartum hysterectomy at full dilatation: Cervical clamp. J Chinese Med Assoc 2018; 81: 366-9.

8. Yaman Tunc S, Agacayak E, Sak S, et al. Multiple repeat caesarean deliveries: do they increase maternal and neonatal morbidity? J Matern Neonatal Med 2017; 30: 739-44.

9. Keag OE, Norman JE, Stock SJ. Long-term risks and benefits associated with cesarean delivery for mother, baby, and subsequent pregnancies: Systematic review and meta-analysis. PLoS Med 2018; 15.

10. De la Cruz CZ, Thompson EL, O’Rourke K, Nembhard WN. Cesarean section and the risk of emergency peripartum hysterectomy in highincome countries: a systematic review. Arch. Gynecol. Obstet. 2015; 292: 1201-15.

11. Knight M, Kurinczuk JJ, Spark P, Brocklehurst P. Cesarean delivery and peripartum hysterectomy. Obstet Gynecol 2008; 111: 97-105.

12. Tahaoglu, A. E., Balsak, D., Togrul, C., et al. Emergency peripartum hysterectomy: our experience. Ir J Med Sci 2016; 185: 833-8.

13. Bakshi S, Meyer BA. Indications for and outcomes of emergency peripartum hysterectomy: A five-year review. J Reprod Med Obstet Gynecol 2000; 45: 733-7.

14. Zeteroglu S, Ustun Y, Engin-Ustun Y, Sahin G, Kamaci M. Peripartum hysterectomy in a teaching hospital in the eastern region of Turkey. Eur J Obstet Gynecol Reprod Biol 2005; 120: 57-62.

15. Engelsen IB, Albrechtsen S, Iversen OE. Peripartum hysterectomy-incidence and maternal morbidity. Acta Obstet Gynecol Scand 2001; 80: 409-12.

16. Zeitlin J, Ashna Mohangoo, Marie Delnord. European Perinatal Health Report. The health and care of pregnant women and babies in Europe in 2010. 2013.

17. Erdemoğlu M, Kale A, Akdeniz N. Obstetrik Nedenlerle Acil Histerektomi Yapılan 52 Olgunun Analizi. Dicle Tıp Derg 2006; 33: 22730.

18. Kayabasoglu F, Guzin K, Aydogdu S, Sezginsoy S, Turkgeldi L, Gunduz G. Emergency peripartum hysterectomy in a tertiary Istanbul hospital. Arch Gynecol Obstet 2008; 278: 2516.

19. Evsen M. S., Sak M. E., Bozkurt Y., Kapan M., Bakır Ç. Nedbesiz uterus rüptürü: Bölgesel insidans, nedenler ve tedavi. Dicle Tıp Derg 2008; 35: 259-63. 
20. Chawla J, Arora CD, Paul M, Ajmani SN. complicated vaginal and cesarean deliveries. Emergency obstetric hysterectomy: A Clin Exp Obstet Gynecol 2017; 44: 20-6. retrospective study from a teaching hospital in north India over eight years. Oman Med J 2015; 30: 181-6.

21. Agacayak E, Basaranoglu S, Tunc SY, et al. A 22. Umezurike CC, Feyi-Waboso PA, Adisa CA. Peripartum hysterectomy in Aba southeastern Nigeria. Aust New Zeal J Obstet Gynaecol 2008; comparison of maternal outcomes in 48: 580-2. 